\title{
Is Environmental Virtue Ethics Anthropocentric?
}

\section{Dominika Dzwonkowska ${ }^{1}$}

Accepted: 13 November 2018 / Published online: 19 November 2018

(c) The Author(s) 2018

\begin{abstract}
Virtue ethics (VE), due to its eudaimonistic character, is very anthropocentric; thus the application of VE to environmental ethics (EE) seems to be in contradiction with EE's critical opinion of human centeredness. In the paper, I prove the claim that there is a possibility of elaborating an environmental virtue ethics (EVE) that involves others (including nonhuman beings). I prove that claim through analyzing Ronald Sandler's EVE, especially his concept of pluralistic virtue and a pluralistic approach to the aim of ethical endeavor which is not only focused on personal flourishing but also helps others (including nonhumans) to flourish. I start my analysis with a close look at the application of anthropocentrism in VE, beginning by discerning the three types of anthropocentrism that are most often used in discussion on EE and EVE, namely ontological, epistemological, and ethical. Subsequently, I analyze the concept of personal flourishing, which is responsible for the anthropocentric/egoistic nature of VE, proving that VE is anthropocentric/egoistic only formally, not in its content, and as such is only a rational theory, not a moral one.
\end{abstract}

Keywords Environmental ethics - Environmental virtue ethics · Ronald Sandler . Anthropocentrism $\cdot$ Eudaimonism $\cdot$ Ethical Egoism

\section{Introduction}

Environmental virtue ethics (EVE) is a result of applying virtue ethics (VE) to environmental ethics (EE). Even though this approach can address the moral aspect of protecting nature quite efficiently, there is a doubt that requires some consideration: $\mathrm{VE}$ is heralded as an anthropocentric ethic and EE is at best non-anthropocentric and often anti-anthropocentric. Thus the marriage of these raises questions about their contradictory perspectives on the position of human in the world. In the paper, I claim that the kind of anthropocentrism (or even egoism) present in VE does not

Dominika Dzwonkowska

d.dzwonkowska@uksw.edu.pl

1 Institute of Ecology and Bioethics, Cardinal Stefan Wyszyński University in Warsaw, Woycickiego 1/3, 01-315 Warsaw, Poland 
prevent VE or EVE from including other human beings and nonhuman beings in the moral consideration.

To understand the nature of the anthropocentric claim of VE, I look closer at the meaning of the term 'anthropocentrism'. I show that what is being discussed under one term is at least three different meanings of anthropocentrism (ontological, epistemological, and ethical). Secondly, I analyze how ethicists understand the anthropocentric (or even egoistic) nature of VE. Here, I will analyze the concept of personal flourishing (eudaimonism), which is blamed for anthropocentric/egoistic nature of VE. I show how VE deals with the egoism charge and I prove that VE is anthropocentric/egoistic only in a sense that is not a hindrance to VE or EVE developing an ethical standpoint involving others (including nonhuman beings). I present my claim based on the example of Ronald Sandler's naturalistic, pluralistic and teleological concept of EVE.

\section{Disambiguating Anthropocentrism}

The discussion between anthropocentrism and non-anthropocentrism has become a cornerstone of environmental philosophy, since "anthropocentrism is for many environmental philosophers the ethical attitude the field was created to overcome" (Minteer 2008, 58). The effort to overcome anthropocentrism has been present in environmental philosophy almost since its beginning: it has its origin in the claim that human-centeredness is the cause of ecological crisis and has limited moral standing to human beings. However, discussion about anthropocentrism is sometimes misleading, since the terms anthropocentrism and anthropocentric are used with various (sometimes conflicting or overlapping) meanings. In this part of the article, I will present the three most often used types of anthropocentrism, namely ontological, epistemological, and ethical ${ }^{1}$ (see Minteer 2008).

\section{Ontological Anthropocentrism}

The first type of anthropocentrism is an ontological one. Ontological anthropocentrism assumes human-centeredness and the privileged position of human beings. It claims a superior ontological position of human beings and perceives them as the pinnacle of creation. This view has often been subject to criticism. According to Minteer (2008, 59), White's (1967) influential article on the roots of environmental crisis has had a significant influence on the rise of criticism of anthropocentrism in environmental ethics. White's criticism is mostly against the ontological stance. In

\footnotetext{
1 In this paper, I decided to focus on three types of anthropocentrism described by Minteer (2008), even though in the environmental literature one can find many types of anthropocentrism that designate either the form of human-centeredness or the intensity of it (for example, strong, weak, prudential, or enlightened anthropocentrism). Some forms of anthropocentrism, at least in some aspects, overlap with the understanding of the types described here, like in the case of epistemological anthropocentrism. Some philosophers (Ferré 1974; Thompson 2017) call the view presented in this paper perspectival or conceptual anthropocentrism.
} 
the paper, he notes that the Judeo-Christian tradition is contradictory to the pagan unity of human beings and nature. White claims that in the Christian tradition man, "was created separately from the rest of Creation, and he alone was given 'dominion' over the creatures of the earth and commanded to 'subdue' them and the earth" (Minteer 2008, 59). The reason for his privileged position is that "man shares, in great measure, God's transcendence of nature" (White 1967, 1205). White's claim has led to a refutation of anthropocentrism as a cause of ecological crisis and established the trend of its criticism in environmental discussion.

However, it has to be emphasized that in philosophy human-centeredness has been criticized at least since the second half of the nineteenth century. David Gunkel, ${ }^{2}$ discussing the roots of anti-anthropocentrism, notes that "since at least Nietzsche, philosophers, anthropologists, and social scientists have been increasingly suspicious of the privileged position human beings have given themselves in the great chain of being, and this suspicion has become an explicit object of inquiry within the so-called human sciences" (Gunkel 2012, 109). ${ }^{3}$ Gunkel claims that anthropocentrism is rooted in later times than White suggests: he points out that it was actually Descartes who erected a wall between human beings and the rest of creation when he divided the world into res cogitans and res extensa, thus putting human beings outside the natural world.

Even though ontological anthropocentrism ${ }^{4}$ is a very important ontological claim, it seems to be irrelevant in the discussion of ethics, since one can be ontologically anthropocentric but still recognize the moral standing of nonhuman world: for example, standpoints claiming that we are custodians of the Earth might assume ontological anthropocentrism but can still recognize the moral standing of nonhuman world (see Skolimowski 1984).

\section{Epistemological Anthropocentrism}

The second type of anthropocentrism is connected with the way we value the world. As Minteer $(2008,59)$ notes, "all human values are human values, including the intrinsic value that ethical non-anthropocentrists ascribe to nature." This leads to an epistemological anthropocentrism, according to which we will never go beyond the human perspective. We know the world from the perspective from which we value, reflect on, think about and analyze the world. Replying to Nagel's (1974) question about the world from the bat's perspective, it can be noticed that "the problem with non-anthropocentrism rests with our inability to access the required knowledge to fully experience being a bat (or any other nonhuman living thing)" (Epting 2017, 136).

\footnotetext{
2 It has to be emphasized that Nietzsche's criticism of the privileged position of the human being was directed toward the concept of human-centeredness in the form of humanism of his time. Thus the concept itself is different in character; however, the basic essence of human-centeredness is the same.

3 More about the Nietzschean approach to non-anthropocentrism can be found in Hatley (2017).

4 This approach can be seen in the philosophies of Aristotle or Thomas Aquinas, or in neo-Thomistic philosophy.
} 
This type of anthropocentrism we cannot escape: whenever someone claims that ethics is anthropocentric since human beings make ethical evaluations, he applies to epistemological anthropocentrism. We will never be able to go beyond the human point of view. It gives us a lens through which we perceive the world. Each ethic and each philosophy is anthropocentric in an epistemological sense. As Parker (1996, 33) notes, "the human organism is inevitably the one that discusses value. This is so because the human perspective on value is the only one we know as humans."

This kind of epistemological anthropocentrism cannot be overcome: it is a necessary kind of anthropocentrism. It is not ascribed to us because we are the only moral agents: it is directly connected with our cognitive capabilities, which are limited to knowing the world from our perspective only. We cannot understand how it is to be a bat, and any ethics or philosophy is anthropocentric in the epistemological sense. However, even perceiving the world from the human perspective only, we still can go beyond anthropocentrism and recognize the intrinsic value of the natural world (see Hargrove 1992). We will never literally think like a mountain (Leopold 1949, 114-118), but we can imagine the perspective of the nonhuman world and our decisions may be more environmentally-oriented. Even though this kind of anthropocentrism is embedded in our nature, it is not a hindrance to elaborating an environmental ethic that includes nonhuman beings.

\section{Ethical Anthropocentrism}

Ethical anthropocentrism is the theoretical standpoint that limits intrinsic value to human beings only and thus attributes moral standing only to humans. Even though human beings evaluate the world, value does not depend on being recognized or on some external valuation. The value of the nonhuman world has not been created by human beings: it has been discovered (Rolston 1986). It has to be emphasized that value is not the same as being valued, and beings do not have value only because of human judgment (see Attfield 1991, 145-161). As Attfield notes, "valuable does not mean 'valued' but applies to what there is reason to value, whether or not anyone values it; and it is implausible that nothing had value (...) until humanity (or possibly until intelligent vertebrates) first appeared and began making judgments" (Attfield 2008, 99-100). There are many examples of ethical approaches that emphasize the value of the nonhuman world: one is the biocentric ethics of Paul Taylor who claims that every living being has an intrinsic value as a teleological center of life with a good of its own (Taylor 1981).

Ethical anthropocentrism is therefore not a necessary feature of ethical theorizing or philosophy in the way that epistemological anthropocentrism is. We as moral agents can recognize the value of the nonhuman world and make decisions about which beings we include in our moral consideration. Ethical anthropocentrism may have its foundation in ontological anthropocentrism, since limiting the moral consideration to human beings only may sometimes be connected with the ontological view of human-centeredness or privileged position. This type of anthropocentrism is the most relevant to the ethical discussion: due to the ethical perspective, the moral 
agent can recognize the moral standing of the nonhuman world and employ a nonanthropocentric point of view.

\section{Is Eudaimonistic Virtue Ethics Anthropocentric?}

As I have shown in previous part the problem with a discussion on anthropocentrism is that philosophers often mix the three types, going too easily from ontological claims to either the ethical or the epistemological. Moreover, some philosophers seem to think that ethical anthropocentrism is implied by the other forms of anthropocentrism, which it is not. Confusing the three different types of anthropocentrism not only blurs ethical discussion. It has to be emphasized that the three types of anthropocentrism apply to three different levels and each has different consequences for ethics, as well as for virtue ethics.

For VE the charge of anthropocentrism is connected with its eudaimonistic character and means basically the agent-centeredness. VE is said to be anthropocentric; it is even charged with being the most anthropocentric approach to ethics in all ancient tradition (see Jaśtal 2006, 45). Since environmental ethicists wanted "to develop a non-anthropocentric ethical position" (Cafaro 2005, 40), VE has been considered incapable of elaborating a theoretical standpoint adequate for environmental discussion. Due to the charge of anthropocentrism, the marriage of VE and EE seems to be at best controversial (Kallhoff and Schörgenhumer 2017; Rolston 2005), and interest in virtue theory in relation to environmental discussion is possible a quarter of a century after the revival of virtue in modern philosophy. ${ }^{5}$

In this part of the paper, I will look closer into the claim that VE is anthropocentric (or even egoistic). As seen above, the term' anthropocentrism' is used in various meanings and the charge of anthropocentrism of VE adds up to a new understanding of human-centeredness, since VE is perceived as anthropocentric due to its agent-centeredness. While environmental philosophers call this attitude anthropocentric, virtue ethicists perceive it as a sign of egoism. The charge of egoism in $\mathrm{VE}$ is in some sense analogous to the claim about anthropocentrism. It has the same root cause, namely the concept of eudaimonism. ${ }^{6}$ In this part of the paper, I analyze the charge of anthropocentrism/egoism of VE and prove that VE is only prima facie anthropocentric/egoistic.

\footnotetext{
${ }^{5}$ Cafaro (2010) points out that the beginning of environmental virtue ethics can be marked Thomas Hill's (1983) article on the Ideals of Human Excellence and Preserving Natural Environment, while the revival of virtue discussion in ethics is attributed to Anscombe's paper published in 1958.

6 It has to be emphasized that not all virtue ethics are eudaimonistic. The Stanford Encyclopedia of Philosophy lists four types of contemporary virtue ethics discussion: 1 . eudaimonist virtue ethics; 2 . agentbased and exemplarist virtue ethics; 3. target-centered virtue ethics; and 4. Platonistic virtue ethics (see Hursthouse and Pettigrove 2016).
} 


\section{The Charge of Anthropocentrism/Egoism of VE}

VE is an agent-centered approach that begins ethical discussion by asking questions: What sort of person would do that? ${ }^{7}$ How should I live? What is the best way to live? What is a good life for human beings? (Van Zyl 2015, 183). These are the questions that should help a moral agent to live a good, happy life and to flourish. ${ }^{8}$ Since ancient times, the cornerstone of virtue ethics was a eudaimonistic concept of virtue, according to which virtues are conducive to a moral agent's flourishing, wellbeing and happiness. Thus, being virtuous is a way to eudaimonia, understood as personal happiness. ${ }^{9}$

Even though aiming at personal happiness sounds like the best motivation to lead an ethical life, it is a troublesome as well, since "eudaimonism is the view that the fundamental intrinsic value in ethics is the human good. In particular [...] an agent's own good" (Prior 2001, 325). This approach raises the consideration of others as morally questionable; and while environmental ethicists see it as a sign of anthropocentrism, contemporary virtue ethicists (for example, Anscombe 1958, 42) are concerned rather about the egoism of this ethical approach.

According to Annas (1993), agent-centered ethical theory is very much in line with the nature of ancient ethics, which "begins with the agent's concern for her own life as a whole. Modern moral theories, by contrast, often begin by specifying morality as a concern for others; morality is often introduced as a point of view contrasting with egoism" (p. 127; see also Hurka 2001). It therefore seems that the cornerstone of ancient ethical theories is the concern of an individual moral agent, and the eudaimonistic concept of virtue is just an incentive to lead an ethical life.

At first glance, it looks like aiming at personal flourishing, explained in such a way, is not merely a sign of anthropocentrism, as environmental ethicists claim. The moral consideration of $\mathrm{VE}$ is not so wide as to include the whole of humanity, but is focused on an individual agent's flourishing. Thus the concept of eudaimonism

\footnotetext{
7 As is the case in Thomas Hill's article (1983), where he narrates the story of covering a beautiful garden with asphalt and asks the question: what sort of person would do that? He does not try to carry out a deontological or consequentialist analysis of this action: instead, he asks about person's attitude toward nature and connected virtues.

${ }^{8}$ It has to be emphasized that virtue ethics is often presented as contrary to predominant ethical approaches (deontological and consequentialist). Even in environmental discussion, "there is a split between those who regard environmental virtue ethics as a complement to the predominant theoretical approaches to environmental ethics (e.g., consequentialist and deontological), and those that regard it an alternative approach" (Sandler 2018, 224). The modern revival of virtue ethics started with criticism of these conceptions of ethics (Anscombe 1958, 5). However, this does not mean that it is limited just to reflection on the flourishing of the moral agent: other elements of theory (like theory of value and normative theory) are important areas of ethical discussion as well.

${ }^{9}$ However, ancient philosophers disagree on whether virtue is the only condition for happiness. Stoics claims that it is sufficient for a happy life, while Aristotle emphasizes that alongside virtue, external goods (like health and wealth) are also needed. Modern virtue ethicists have different points of view: McDowell (1980, 359-376) supports the claim that virtue is necessary and sufficient for human flourishing, while Hursthouse (1999) claims that bad luck can prevent a virtuous person from leading a happy life, and Swanton (2003) uses the example of a moral saint to present that a link between virtue and happiness is not as strong as its supporters claim (Van Zyl 2015, 183, 191-192).
} 
disables even the inclusion of other human beings, since VE framed in this way employs only the human perspective (epistemological anthropocentrism) and limits the moral consideration to human beings only (ethical anthropocentrism) or even only to individual moral agents (egoism). ${ }^{10}$ Although VE might seem to be anthropocentric or egoistic, not all philosophers agree with the point of view presented above. In the next part of the paper, I will examine how ethicists answer the charge of the egoistic character of eudaimonism.

\section{The Anthropocentrism/Egoism of VE Revisited}

VE is considered anthropocentric because of its agent-centeredness and aim at personal flourishing. Taken as such, it represents epistemological anthropocentrism, since the moral agent is the one that takes the moral decision from the very human perspective, and every ethical approach is an example of epistemological anthropocentrism. Moreover, virtue ethics understood in such a way represents ethical anthropocentrism since the moral consideration is limited to the moral agent himself. However, what is being stated by the egoistic charge is not the full picture of virtue.

First of all, some of the virtues are directly connected with our care for the good of other people. The virtue of friendship, highly esteemed by Aristotle, involves personal flourishing as well as our friend's flourishing. Moreover, Annas (1993) emphasizes that virtues are not developed to achieve the end goals of the moral agent: if a moral agent acts just for the purpose of personal aims, then his actions are not virtuous at all. Virtues are the dispositions that direct our actions to do what is in line with our virtuous character traits. Thus "an ethics of virtue is therefore at most formally self-centered or egoistic; its content can be fully as other regarding as that of other systems of ethics" (Annas 1993, 127).

Annas also confutes the argument that a self-centeredness of VE is problematic for virtue ethics. She claims that the good of the other can be important for the moral agent independently of his own interests. Good of the other is often opposed to one's own interests. However, Annas (1993) claims that the good of other people can be as important for a moral agent as his own good, or it can be a motivation. There are even virtues whose nature is caring for the interests of the other more than for our own, like the virtues of care. Anscombe $(1958,42)$ also refutes her concerns about the egoism of VE, contending that her consideration of the agent's centeredness on his own aims distinguishes between morality and rationality: the former considers questions about the rightness and wrongness of action, while the latter asks about the moral agent's reasons for performing the action and whether those are egoistic. ${ }^{11}$

Thus it seems that virtue ethics is egoistic only formally, or is taken as a rational theory. One reason why virtue ethics may have been recognized as an egoistic theory

\footnotetext{
${ }^{10}$ It has to be emphasized that some philosophers claim that VE should accept some forms of egoism-not the one understood very broadly, but still egoism in some form should be a part of our ethical endeavor (see Toner 2015, 345).

11 See also Hursthouse (1997).
} 
is the misleading translation of eudaimonia as happiness. Eudaimonia is not just a good mood, ${ }^{12}$ excitation or anything that is attributed to this term in common parlance; it is a special type of happiness, a moralized concept of happiness (see Swanton 2003, 87-90). It is a virtue-driven concept of a happy life, where what is satisfying for a virtuous person is not what is satisfying for an unvirtuous one: "Pleasure is not even in one's self-interest (good for one) unless it is infused with suitable virtue" (Swanton 2003, 87). As an example, Swanton gives the virtue of friendship that was so much appreciated by Aristotle. According to her, the virtue, if it is used only for complaint and lamentation, is harmful for both friends: only a virtuous person has the kind of character traits that enable a genuine human flourishing and happiness for good reasons.

For example, if a caring person decides to help a friend in need and to make a big effort to relieve the friend's suffering, even though for the other it might seem to be a huge sacrifice, the moral agent would not consider it a sacrifice; or even if he finds it a sacrifice, he still sees a higher good in helping the friend than in what had to be sacrificed. Ronald Sandler $(2018,227)$ calls this an integrative effect of virtue, that makes an environmentally-committed person take pleasure in activities the other might perceive as a burden. Thus, the moral agent is able to act for the other and does not consider it as a sacrifice or a loss even if it is. Virtues are good for the moral agent as well as for his community. According to Foot (2002, 2-3), some virtues are beneficial for the moral agent, while some are good for his community.

However, it has to be emphasized that all virtues make the moral agent excellent in some way-namely, in the context of benefits we can distinguish intrinsic and consequential benefits. In some sense, virtues are beneficial for the agent himself and/or for others. Prior (2001, 329-330) emphasizes that in Aristotelian virtue ethics, "a good life is essentially characterized by excellence in rational activity, ${ }^{13}$ every act that makes excellent use of reason, every virtuous act, contributes essentially to the good life of an agent". Thus every virtuous action will benefit the moral agent intrinsically at least at some level (sometimes only due to the rational activity described above) and some virtuous actions in certain situations may also benefit the moral agent's community. Virtues bring benefits not only for the moral agent but also for the wider community. Stoic philosophy also supports the claim that eudaimonism can exceed self-centeredness. Annas (1993) notes that even though the stoics begin from a point of concern about the moral agent and his happiness, they "end up claiming that the end of this development will precisely be a position where, as far as the claims of morality go, one is indifferent between one's own interests and those of someone one has no knowledge of in a far-away country" (p. 128).

Eudaimonistic VE is only formally ${ }^{14}$ self-centered or even egoistic (Annas 1993, 127), or it is such only as a rational theory, not as a moral one (Anscombe 1958). Even though it is only prima facie anthropocentrism or egoism, it may be delusive:

\footnotetext{
12 For more on this, see Russel (2013, 11-18).

13 Rational activity and practical wisdom are crucial concepts in virtuous action. McDowell (1979) claims that virtue is actually practical wisdom.

14 It seems to be egoistic or anthropocentric, but its content is not such at all.
} 
"The chief fault with eudaimonism in the minds of modern moral philosophers is its grounding of ethical motivation in the good of an agent. This runs counter to a widespread intuition among moral philosophers that the business of moral philosophy is the justification of action that is entirely objective and other-regarding" (Anscombe 1958, 338). It has to be recognized that virtues are beneficial for the moral agent in many ways that are not contradictory to the concept of others flourishing. VE can be as other-involving as other ethical approaches; furthermore, it does not have to be limited to moral consideration of human beings only, which proves Ronald Sandler's virtue-oriented ethics.

\section{An Example of Ethically Non-Anthropocentric EVE: Sandler's EVE}

The claim that virtue ethics is anthropocentric has been a reason for excluding this approach from environmental ethics for so long. However, a eudaimonistic VE is only prima facie anthropocentric and it enables elaborating the ethical standpoint that includes others, as well as nonhuman others. There are many interesting approaches to EVE which prove this. Among them, some should be mentioned as the most elaborated theories: Philip Cafaro's approach, which is built on the foundation of Thoreau's philosophy (Thoreau 1854; Cafaro 2004); Louke van Wensveen's (2000) dirty virtues ethics; Brian Treanor's (2014) narrative approach; and Ronald Sandler's (2007) virtue-oriented environmental ethics. ${ }^{15}$ Even though each of these approaches is a very insightful and interesting input into the virtue discussion in environmental ethics, in this paper I focus only on Sandler's approach, since this EVE employs the pluralistic and teleological approach that is conducive to human and nonhuman flourishing.

In my opinion, Sandler's EVE makes an important contribution to the anthropocentrism discussion. ${ }^{16}$ His approach is inspired by Hursthouse's (1999) and Foot's (2001) naturalistic virtue ethics approach. Thus Sandler's EVE is naturalistic, as well as pluralistic and teleological. According to Sandler, the good life is the realization of those needs that are important for us as a specific kind of species. According to this approach, a human being is virtuous:

insofar as she is well fitted with respect to her (i) emotions, (ii) desires, and (iii) actions (from reason and inclination): whether she is thus well fitted is determined by whether these aspects well serve (1) her survival, (2) the continuance of the species, (3) her characteristic freedom from pain and characteristic enjoyment, (4) the good functioning of her social group, (5) her autonomy, (6) the accumulation of knowledge, (7) a meaningful life, and (8) the realization of any noneudaimonistic ends (grounded in noneudaimonistic

\footnotetext{
15 However, many more philosophers have made an interesting contribution to EVE, including Rosalind Hursthouse, Jennifer Welchman, Allen Thompson, Geoffrey Frasz, Bill Shaw, Holmes Rolston III, Lisa Newton, Isis Brooke, John O’Neil, Thomas Jr. Hill, Val Plumwood, Jason Kawall, and Rebecca Walker.

16 Even though Fox $(2008,421)$ claims that Sandler's ethics is anthropocentric, it has to be noted that this approach to EVE makes an important input that goes beyond anthropocentrism.
} 
goods or values) in the way characteristic of human beings (i.e., in a way that can rightly be seen as good) (Sandler 2007, 28).

The concept of pluralism is here crucial for elaborating ethics that include in our moral consideration not only the moral agent or his species but a wider circle of entities. First of all, this approach assumes a pluralistic account of virtue in terms of whom we should include in our moral consideration. This enables the inclusion of a wide variety of beings (also nonhuman entities) in our moral choices. Secondly, it offers a pluralistic view on the teleological approach. ${ }^{17}$ It does not limit the concept of the aim of ethical endeavor to personal eudaimonia and it enables including noneudaimonistic goals. Thus the happiness of the other might be the aim of our actions. Moreover, our care for others is not limited to human beings only. In the following paragraphs, I will present those aspects of a pluralistic approach to virtue and teleology that are conducive to including nonhuman entities in our moral consideration and thus overcoming egoism and anthropocentrism.

\section{The Pluralistic Account of Virtue and Teleology}

Sandler's approach to virtue may be very productive in overcoming the concept of human transcendence claimed by White or the 'wall' erected by Descartes. As Sandler claims, environmental ethics must avoid metaethical dogmatism: "we ought not believe [...] that only one sort of environmental ethics, such as anthropocentric, holistic, or intrinsic value-based environmental ethics, can be adequate" (Sandler $2007,119)$. This approach, which is very often included in environmental ethics, is often depicted in the form of concentric circles. This starts from the individual (egoism), and some claim that VE can be classified here. The circle grows bigger, limiting moral consideration to one's family (nepotism), fellow citizens (patriotism), all humanity (anthropocentrism), all sentient beings (sentientism), all living individuals (biocentric individualism), and finally reaching moral considerability of all ecosystems (ecocentrism) (see Sandler 2007, 40).

As the circle expands, it seems to salve our conscience with the idea that we have included in our moral considerability every being that should be included. However, there are some difficulties here, like the one raised by Thomas Birch, who claims that moral considerability is an exclusive concept that is built on mark/marks of membership to the club of consideranda (Birch 1993, 315). It raises a wall between those who enter the circle and those who are outside it; so, whatever 'centrism' there is, it is still not as wide and encompassing as it could be. In whatever way we define the criteria for moral considerability, it remains a very imperfect theoretical construct. It is not inclusive enough, always exclusive on the basis of some mark/s, always erecting a wall in the same sense as Descartes has done. So, even though we may push the Cartesian wall further in some sense, it is still not a fully satisfactory approach. I do not mean that boundaries are wrong and that our ethics should

\footnotetext{
17 Since pluralism in terms of both virtue and teleology applies to moral considerability, they will be presented together instead of splitting the two concepts into two separate paragraphs.
} 
include all entities: that would be unfeasible; however, I wanted to highlight that any circle creates theoretical problems, like epistemological grey areas or inadequacy of our ethical experience (Sandler 2007, 40).

This is why the pluralistic approach to moral considerability is necessary. For Sandler, "pluralism in moral considerability is accommodated within the purview of different virtues, which are differentiated by the types of objects, events and properties to which they are responsive (their bases of responsiveness) and the types of reactions and activities they involve (their forms of responsiveness)" (Sandler 2007, 40-41). For compassion, the basis of responsiveness might be the suffering of the other and the forms of responsiveness might be many, among them concern for the other, a desire to assist the other, or taking action to alleviate the suffering of the other.

"Moreover, there is no mechanism [...] for establishing one type of moral considerability as superordinate to another in principle" (Sandler 2007, 40). The numerous environmental virtues respond to the multifariousness of objects, events or properties (virtue's basis of responsiveness) in multiple ways (forms of responsiveness). The pluralistic approach is one example of how Sandler's EVE escapes the anthropocentrism-non-anthropocentrism dichotomy, or the circle's exclusion problem. Sandler recognizes that the multifariousness of our relations with nature cannot be fully expressed by one basis/form of responsiveness. Different virtues respond to various stimuli in multiple ways: thus a virtue cannot be limited to one centrism. Virtue-oriented ethics proves that virtues can be helpful in recognizing the moral standing of nonhuman entities. Moreover, this approach can be conducive to going beyond the goals set by eudaimonistic ethics.

The other form of going beyond the questions raised by anthropocentrism criticism is the problem of eudaimonism understood as aiming at personal flourishing. Sandler's EVE goes beyond eudaimonistic determinations by introducing a pluralistic account of teleology. He contends that environmental virtue is not limited to the realization of eudaimonistic aims only: it recognizes the role of noneudaimonistic aims in human flourishing. Furthermore, the concept of flourishing is not limited to human beings only, and environmental virtue can be conducive to nonhuman flourishing, since the human being is a part of both the natural and the cultural world.

\section{The Others (Human) Flourishing}

The virtue that enables us to go beyond personal flourishing the most is benevolence. Sandler points out that benevolence is important in two respects: 1) if it promotes personal eudaimonia; and 2) if other entities have worth or value that the moral agent has a reason to respond to. There are two types of benevolence: passive (considerateness and nonmaleficence) and active (for example, helpfulness, compassion, or charitableness) (Sandler 2007, 53). The virtues of benevolence are crucial for the moral agent to flourish in society, to live well as a member of a community, and these are the virtues that are conducive to the realization of both eudaimonistic and non-eudaimonistic ends. 
Environmental virtues are a special type of virtue that can contribute to human flourishing in various ways. Environmental virtues are "appropriate attitudes in addressing nature and in profiting from nature" (Kallhoff and Schörgenhumer 2017, 194). There is no doubt that human beings benefit from nature in many ways, starting from the very basic naturalistic implications of our reliance on the services provided by the ecosystem. Thus recognition of their value and aiming at ecosystem sustainability (see van Wensveen 2000; 2001) is not a matter of a sophisticated ethical dispute. It is a matter of protecting our existence. ${ }^{18}$

Ronald Sandler presents a wide spectrum of mutual benefits of cultivating environmental virtues. For example, virtues of environmental activism ${ }^{19}$ can not only bring benefits to nature but can help individuals to succeed in other domains (Sandler 2007, 49); or the benefit of wonder for the natural world can, according to Rachel Carson, provide joy, exhilaration, or satisfaction and is a gateway to love, gratitude, appreciation, and care (Sandler 2007, 50). Thus the other types of ecosystem service are also important for us as human beings, either in a naturalistic way or more subtly. ${ }^{20}$ Recognition of the value of nature is itself an element of human flourishing. It helps to shape a "person's ethical outlook to reflect what things are actually worth" (Sandler 2007, 31). On the one hand, it promotes the Aristotelian way of perceiving virtue, which is connected with excellence in rational activity; on the other hand, it supports promoting agent and agent-independent ends.

\section{Nonhuman Others' Flourishing}

Thus environmental virtues can be beneficial for human beings' flourishing; however, the crucial question is whether they can also contribute to nonhuman flourishing. According to Sandler's definition, environmental virtues are those character traits that promote human and nonhuman flourishing. ${ }^{21}$ The pluralistic account of virtue enables a moral agent to recognize the value of natural goods and respond to them in a virtuous way. This is environmentally responsive virtue-i.e. the type of virtue "for which environmental entities are morally considerable" (Sandler 2007, 42). The other type of environmental virtue is the one that is environmentally justified. This kind of virtue is when "a character trait is justified as a virtue at least in part by environmental goods and values-be they instrumental goods (e.g., natural resources or ecosystem services) or final values (e.g., natural value or inherent worth)" (Sandler 2018, 224). When a certain character trait is conducive to the accomplishment of environmental ends or goals (e.g., it promotes sustainability or contributes to the flourishing of nonhuman organisms) then it is an environmentally

\footnotetext{
18 Even though this notion brings several theoretical problems (see Sandler 2007, 44-49).

19 For example, cooperativeness, perseverance, optimism, creativity.

${ }^{20}$ For example, cultural ecosystem services that enable us to create pieces of art including nature or inspired by nature, or spiritual or recreational experiences in natural surroundings, or making nature a subject in science or education.

21 Sandler Ronald, An Interview with Ronald Sandler, available at: <https://cup.columbia.edu/autho r-interviews/ sandler-character-environment > accessed: 26.03.2018.
} 
productive virtue. The concept of environmental virtue includes non-agential ends. It can aim at promoting nonhuman flourishing (environmentally productive virtue), its justification may be care for the environment (environmentally justified virtue), and it recognizes the moral standing of the nonhuman world.

As Swanton (2003, 92-93) notes, "some virtues [...] serve ends other than human flourishing; for example, the flourishing or integrity of natural objects and systems, whether sentient, living or non-living".. Sandler supports this claim in reference to virtues of benevolence and provides arguments that show how virtues of interpersonal benevolence can promote both human and nonhuman flourishing. He contends that a benevolent person will contribute to the protection of environmental goods, since they are necessary for humans' health and survival. Thus interpersonal benevolence is an important factor in promoting environmental wellbeing, as well as caring for human flourishing. ${ }^{22}$

The benefits of virtue cultivation are not limited to human flourishing. Virtues are not cultivated in a societal vacuum and the virtuous person is the one that is disposed to act in a way that is beneficial for her and for her surroundings. Environmental virtues are those character traits that promote human and nonhuman flourishing. For example, if we practice moderation, it helps us to develop various qualities that are beneficial for ourselves, such as discrimination (to analyze whether we need to buy a new good), self-restraint, patience, and many others. Meanwhile, we also make a contribution to a more reasonable resource usage and reduce resource waste, which is crucial to stop ecosystem degradation. It is beneficial for both the moral agent himself as well as for his surroundings and for nature. Thus environmental virtues help the moral agent to flourish while being beneficial for nonhuman flourishing. This approach to EVE is non-anthropocentric in three ways: 1) nonhuman ends are the justification of virtue; 2) agent flourishing can involve nonhumans; and 3) virtue can be productive of nonhuman flourishing.

However, a consideration regarding epistemological anthropocentrism is raised by Holmes Rolston III. He points out that

environmental virtues, as achieved by humans, will initially involve concern for human quality of life. But our deeper ethical achievement needs to focus on values as intrinsic achievements in wild nature. These virtues within us need to attend to values without us ... The other cannot be seen simply as a source of personal transformation. We must make the model at least an ellipse with two foci: human virtue and natural value" (Rolston 2005, 69).

Ronald Sandler addresses this problem by applying to the relational nature of virtues, that are not "excellent in themselves [...] They are excellences in relating to the world. (...) The bases of the virtues, therefore, include entities with inherent worth and values «without us»" (2007, 112-113). Thus we are able to perceive and

\footnotetext{
22 However, there are still problems included in this issue, like equal share of resources (especially in areas or communities where there is limited access) or priority of the virtues of benevolence in an environmental context over other types of virtue that are not conducive to securing environmental goods, or very anthropocentric reasons to protect nature.
} 
include into our moral choices the values and worth of the natural world. The pluralistic bases of responsiveness make it possible to include the values and worth of the natural world. This approach is therefore still able to go beyond the limiting of flourishing to human beings only. Sandler's EVE is an example of ethics that enables the realization of eudaimonistic and noneudaimonistic aims. This is an approach to ethics that includes a wider scope of moral consideration than does eudaimonistic ethics. Thus it enables including human beings as well as providing benefits for nonhuman beings.

\section{Summary}

The effort to overcome anthropocentrism has become a cornerstone of environmental discussion. Even though many brilliant philosophers have contributed to it, the problem has not been solved in a satisfactory way. Moreover, proposed solutions (like biocentrism or ecocentrism) have brought some theoretical problems that are difficult to overcome. One of the biggest difficulties in overcoming anthropocentrism is not the problem itself, but the terminological chaos that is present in the discussion. The term anthropocentrism is most often used in three meanings: 1) ontological anthropocentrism, 2) ethical anthropocentrism, or 3) epistemological anthropocentrism. It is important to make a distinction here, since each of these approaches brings different consequences for the ethical theory. It is also important to recognize that ethical anthropocentrism is the one that is of primary importance for ethical discussion and it is the concept that can help to deal with an ecological crisis.

The crucial aspect of criticism toward virtue ethics is that it is agent-centered and focused on human flourishing. In the paper, I have shown that agent-centeredness does not enable VE to elaborate the ethical approach that is including the others. Ronald Sandler's ethics is an example of virtue-oriented ethics that is non-anthropocentric in an ethical sense and that recognizes virtue as a tool for both human and nonhuman flourishing.

Acknowledgements The paper is the result of research carried out within the research project "The scope of moral reflection in Ronald Sandler's environmental virtue ethics" financed by the National Science Center in Poland (Decision no 2017/01/X/HS1/01491). I owe huge thanks to Ronald Sandler, who has read numerous versions of this paper and given lots of insightful comments. I also thank John Basl for valuable remarks on the paper's draft.

Open Access This article is distributed under the terms of the Creative Commons Attribution 4.0 International License (http://creativecommons.org/licenses/by/4.0/), which permits unrestricted use, distribution, and reproduction in any medium, provided you give appropriate credit to the original author(s) and the source, provide a link to the Creative Commons license, and indicate if changes were made.

\section{References}

Annas, J. (1993). The morality of happiness. New York: Oxford University Press.

Anscombe, G. E. M. (1958). Modern moral philosophy. Philosophy, 33, 1-19.

Attfield, R. (1991). Postmodernism, value and objectivity. Environmental Values, 10, 145-162. 
Attfield, R. (2008). Biocentrism. In J. B. Callicott \& R. Frodeman (Eds.), Encyclopedia of environmental ethics and philosophy (pp. 97-100). Detroit: Gale.

Birch, T. H. (1993). Moral considerability and universal consideration. Environmental Ethics, 15(4), 313-332.

Cafaro, P. (2004). Thoreau's living ethics. Walden and the pursuit of virtue. Athens: University of Georgia Press.

Cafaro, P. (2005). Thoreau, Leopold, and Carson: Toward an environmental virtue ethics. In R. Sandler \& P. Cafaro (Eds.), Environmental virtue ethics (pp. 31-44). Oxford: Rowan \& Littlefield Publishers.

Cafaro, P. (2010). Environmental virtue ethics special issue: introduction. Journal of Agricultural and Environmental Ethics, 23(3), 3-7.

Epting, S. (2017). On moral prioritization in environmental ethics: weak anthropocentrism for the city. Environmental Ethics, 39(2), 131-146.

Ferré, F. (1974). Personalistic organicism: paradox or paradigm? Royal Institute of Philosophy Supplement, 36, 59-73.

Foot, P. (2001). Natural goodness. Oxford: Oxford University Press.

Foot, P. (2002). Virtues and vices and other essays in moral philosophy. New York: Oxford University Press.

Fox, M. A. (2008). Character and environment: a virtue-oriented approach to environmental ethics by Ronald Sandler. Review. Environmental Values, 17(3), 419-422.

Gunkel, D. J. (2012). The machine question. critical perspectives on AI, Robots, and ethics. Cambridge: MIT Press.

Hargrove, E. (1992). Weak anthropocentric intrinsic value. The Monist, 75(2), 183-207.

Hatley, N. A. (2017). The early Nietzshe's alleged anthropocentrism. Environmental Ethics, 2017(2), $161-173$.

Hill, T. (1983). Ideals of human excellence and preserving natural environment. Environmental Ethics, $5(3), 211-224$.

Hurka, T. (2001). Virtue, vice, and value. Oxford: Oxford University Press.

Hursthouse, R. (1997). Virtue theory and abortion. In R. Crisp \& M. Slote (Eds.), Virtue ethics. Oxford: Oxford University Press.

Hursthouse, R. (1999). On virtue ethics. Oxford: Oxford University Press.

Hursthouse, R. \& Pettigrove, G. (2016). Virtue ethics. The Stanford Encyclopedia of Philosophy. https:// plato.stanford.edu/cgi-bin/encyclopedia/archinfo.cgi?entry=ethics-virtue. Accessed 15 March 2018.

Jaśtal, J. (2006). Etyka cnót wobec wyzwań etyki środowiskowej: spór o granice naturalistycznego dyskursu etycznego. Diametros, 9, 34-50.

Kallhoff, A., \& Schörgenhumer, M. (2017). The virtues of gardening: a relational account of environmental virtues. Environmental Ethics, 39(2), 193-210.

Leopold, A. (1949). A Sand County Almanac. London: Oxford University Press.

McDowell, J. (1979). Virtue and reason. Monist, 62, 331-350.

McDowell, J. (1980). The Role of Eudaimonia in Aristotle's ethics. In A. Rorty (Ed.), Essays on Aristotle's ethics (pp. 359-376). Berkley: University of California Press.

Minteer, B. A. (2008). Anthropocentrism. In J. B. Callicott \& R. Frodeman (Eds.), Encyclopedia of environmental ethics and philosophy (pp. 58-62). Detroit: Gale.

Nagel, T. (1974). What is it like to be a bat? Philosophical Review, 83(4), 435-450.

Parker, K. (1996). Pragmatism an environmental thought. In A. Light \& E. Katz (Eds.), Environmental pragmatism (pp. 21-37). New York: Routledge.

Prior, W. J. (2001). Eudaimonism and virtue. The Journal of Value Inquiry, 35(3), 325-342.

Rolston, H., III. (1986). Philosohy gone wild: essays in environmental ethics. Amherst NY: Prometeus.

Rolston, H., III. (2005). Environmental virtue ethics: half the truth but dangerous as a whole. In R. Sandler \& P. Cafaro (Eds.), Environmental virtue ethics (pp. 61-78). Oxford: Rowman and Littlefield Publishers.

Russel, D. C. (2013). Virtue ethics, happiness, and the good life. In D. C. Russel (Ed.), The Cambridge companion to virtue ethics (pp. 7-28). New York: Cambridge University Press.

Sandler, R. (2007). Character and environment. a virtue-oriented approach to environmental ethics. New York: Columbia University Press.

Sandler, R. (2018). Environmental ethics. theory in practice. New York: Oxford University Press.

Sandler, R. An Interview with Ronald Sandler. https://cup.columbia.edu/author-interviews/sandler-chara cter-environment. Accessed 26 March 2018.

Skolimowski, H. (1984). Eco-ethics as the foundation of conservation. The Environmentalist, 7, 45-51. 
Swanton, C. (2003). Virtue ethics: a pluralistic view. Oxford: Oxford University Press.

Taylor, P. (1981). The ethics of respect for nature. Environmental Ethics, 3(3), 197-218.

Thompson, A. (2017). Anthropocentrism: humanity as Peril and promise. In S. Gardiner \& A. Thompson (Eds.), The Oxford handbook of environmental ethics (pp. 77-90). New York: Oxford University Press.

Thoreau, H. D. (1854). Walden; or, life in the woods. https://archive.org/details/waldenorlifeinwo1854 thor. Accessed 25 March 2018.

Toner, Ch. (2015). Virtue ethics an egoism. In In L. Besser-Jones \& M. Slote (Eds.), The Routledge companion to virtue ethics (345-357). New York: Routledge.

Treanor, B. (2014). Emplotting virtue: a narrative approach to environmental virtue ethics. Albany: SUNY Press.

van Wensveen, L. (2000). Dirty virtues: the emergence of ecological virtue ethics. New York: Prometheus Books.

van Wensveen, L. (2001). Ecosystem sustainability as a criterion for genuine virtue. Environmental Ethics, 23(3), 227-241.

Van Zyl, L. (2015). Eudaimonistic virtue ethics. In L. Besser-Jones \& M. Slote (Eds.), The Routledge companion to virtue ethics (pp. 183-195). New York: Routledge.

White, L. (1967). The historical roots of our ecological crisis. Science, 10 march, 1203-1207. 